\title{
Effects of freshwater input and mariculture (bivalves and macroalgae) on spatial distribution of nanoflagellates in Sungo Bay, China
}

\author{
Jiachang Lu ${ }^{1}$, Lingfeng Huang ${ }^{2, *}$, Yuanrong Luo $^{2}$, Tian Xiao ${ }^{3}$, Zengjie Jiang ${ }^{4}$, \\ Linnan $\mathrm{Wu}^{1}$ \\ ${ }^{1}$ College of Ocean and Earth Sciences, Xiamen University, Xiamen 361102, PR China \\ ${ }^{2}$ Key Laboratory of the Ministry of Education for Coastal and Wetland Ecosystem, Xiamen University, Xiamen 361102, PR China \\ ${ }^{3}$ Key Laboratory of Marine Ecology and Environmental Sciences, Institute of Oceanology, Chinese Academy of Sciences, \\ Qingdao 266071, PR China \\ ${ }^{4}$ Key Laboratory of Sustainable Development of Marine Fisheries, Ministry of Agriculture, \\ Yellow Sea Fisheries Research Institute, Chinese Academy of Fishery Sciences, Qingdao 266071, PR China
}

\begin{abstract}
Sungo Bay in northern China has been used for rearing bivalves and macroalgae for several decades. The bivalve culture areas (B-area) are located in the bay head, and the macroalgae culture areas (M-area) are located outside of the B-area. In field investigations, we compared the nanoflagellates (NF) in the B-area and the M-area during 4 seasons. After the field investigations, enclosure experiments were conducted during summer to study the effects of mariculture (bivalves and macroalgae) on NF. In the warm seasons (summer and autumn), during which there was an obvious freshwater input to the bay (especially during summer), NF abundance was negatively related to salinity and was higher in the B-area than in the M-area. In the enclosure experiments, an increase in NF abundance was observed after Day 4 in the bivalve enclosure, but not in the macroalgae enclosure. Considering that the B-area was the area of lower salinity, and the season of largest freshwater input was also the optimal growth season for bivalves, we suggest that the spatial distribution of NF in the warm seasons in Sungo Bay may be influenced by both freshwater input and mariculture.
\end{abstract}

KEY WORDS: Nanoflagellates $\cdot$ Mariculture $\cdot$ Freshwater input $\cdot$ Sungo Bay

\section{INTRODUCTION}

Nanoflagellates (NF) are a key component of the microbial loop. Phagotrophic NF, which include heterotrophic nanoflagellates (HNF) and mixotrophic $\mathrm{NF}$, are predators of heterotrophic bacteria and photosynthetic picoplankton, and therefore play a pivotal role in transferring prokaryotic and eukaryotic picoplankton production to the classic food web (Sanders et al. 2000, Calbet et al. 2001, Chan et al. 2009, Tsai et al. 2011). From the early formalisation of the microbial loop concept to present-day research,

${ }^{*}$ Corresponding author: huanglf@xmu.edu.cn the seasonal and spatial variation of NF and the environmental factors have been widely studied in both freshwater and marine systems because of the significant ecological role of NF in aquatic food webs. Generally, temperature, chlorophyll a (chl a), nutrient concentrations and prey (bacteria and picophytoplankton) biomass are the major controlling factors in the spatial distribution of NF (Kuuppo 1994, Safi \& Hall 1997, Granda \& Anadón 2008, Huang et al. 2008). However, there have been few studies on NF in aquaculture areas, which are more readily affected by human activities and more closely associated with our daily lives. 
NF can be captured by bivalves (Dupuy et al. 1999). In contrast, picoplankton are too small to be efficiently retained by most bivalves (Kreeger \& Newell 1996). Therefore, NF may represent a trophic link between picoplankton and filter-feeding bivalves (Le Gall et al. 1997, Dupuy et al. 1999). The ingestion and assimilation of bacterial carbon via NF has been demonstrated in mussels (Kreeger \& Newell 1996). In some bivalve culture ponds, NF were shown to be an important food source for oysters (Dupuy et al. 2000a,b, 2007). Meanwhile, some bivalves may significantly increase dissolved organic carbon (DOC) concentrations in the surrounding water (McKee et al. 2005).

Carbon fixed by macroalgae during photosynthesis is mainly used to produce structure and storage products. However, excess carbon, accounting for up to $40 \%$ of the carbon produced daily during photosynthesis, is released as DOC into the surrounding water (Sieburth 1969, Lucas et al. 1981). Some protists can utilise seaweed-derived polysaccharides and other types of high-molecular-weight polysaccharides (Sherr 1988, Armstrong et al. 2000), whereas bacteria are considered the main consumers of DOC, which is then transferred to higher trophic levels when bacteria are consumed as prey (i.e. by NF). Therefore, seaweeds influence NF through direct or indirect pathways (Armstrong et al. 2000).

Sungo Bay has been used for mariculture since the first successful aquaculture attempts using the seaweed Laminaria japonica in 1970. Over the past several decades, mariculture has expanded in this area, and the aquaculture species have changed from the original monoculture of macroalgae to the present polyculture of macroalgae and bivalves (Fang et al. 1996). The bivalves cultivated mainly include Chlamys farreri and Crassostrea gigas, the retention efficiency of which is reported to drop with decreasing prey size (Dupuy et al. 1999, Zhang et al. 2010). To attain higher production rates and improve aquatic environments, several studies have been conducted in Sungo Bay (Fang et al. 1996, Zhao et al. 1996, Bacher et al. 2003, Mao et al. 2006), and mathematical models have been developed for use in aquaculture assessment and management. However, the microbial loop was not taken into account in these models, despite the microbial loop being important in aquatic systems (Bacher et al. 2003, Nunes et al. 2003, Zhang et al. 2009). The microbial loop may have been ignored in previous studies in Sungo Bay due to a lack of knowledge regarding the in situ components of the microbial loop. Moreover, picophytoplankton blooms have frequently appeared in recent years (Kong et al.
2012). NF are regarded as a significant consumer of picoplankton (Christaki et al. 2005, Bręk-Laitinen \& Ojala 2011); NF most likely play an important role in the Sungo Bay mariculture ecosystem.

This report presents the first study of the NF in Sungo Bay. The major objective of this study was to evaluate the effects of environmental factors and mariculture on the spatial distribution of NF in the field. The spatial distributions of NF and the relationships between environmental factors and NF distribution were obtained by field surveys. Enclosure experiments in situ were conducted to study the effects of mariculture on NF.

\section{MATERIALS AND METHODS}

\section{Sampling}

Sungo Bay, located on the northwest coast of the Yellow Sea, China, is used for raft mariculture of bivalves (Chlamys farreri and Crassostrea gigas) and macroalgae (Laminaria japonica and Gracilaria lemaneiformis). Based on our investigation, the culture density of Chlamys farreri was about $390 \mathrm{~g} \mathrm{~m}^{-3}$ (wet weight) and G. lemaneiformis was about $200 \mathrm{~g} \mathrm{~m}^{-3}$ (wet weight). The cultivation method is longline culture. The organisms are hung into the water column from 0.5 to $7 \mathrm{~m}$. The bivalve culture areas (B-area) are located in the bay head, and the macroalgae culture areas (M-area) are located outside of the B-area (Fig. 1). Samples were collected during 4 trips to Sungo Bay in spring (April 2011), summer (August 2011), autumn (October 2011) and winter (January 2012). Seawater samples were collected using Ruttner bottles (Hydro-Bios). For sites with a water depth of $<10 \mathrm{~m}$, water samples were taken at a depth of $0.5 \mathrm{~m}$ below the surface. For sites with a depth $>10 \mathrm{~m}$, samples were taken at a depth of $10 \mathrm{~m}$. We did not find a significant ( $\mathrm{p}>0.05$, paired $t$-test) difference in NF assemblages between $0.5 \mathrm{~m}$ and $10 \mathrm{~m}$ depths; therefore, average values were used in our results. Water temperature and salinity were measured in situ using a YSI Professional Plus meter at the time of sample collection.

\section{Epifluorescence microscopy analysis of NF}

Samples $(100 \mathrm{ml})$ used to estimate the abundance of NF were pre-filtered through a nylon mesh $(20 \mu \mathrm{m}$ pore size), then fixed immediately by adding glutaraldehyde $(0.5 \%$, final concentration). Subsamples 


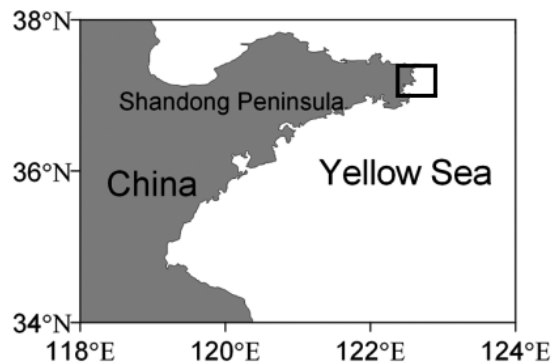

Fig. 1. Sampling stations $(\bullet)$ in Sungo Bay (right panel), on the NW coast of the Yellow Sea (left panel). Light grey area marks the macroalgae culture areas (M-area), while the stations outside the light grey area are the bivalve culture areas (B-area). Enclosure experiments were conducted at Stn S13 (४)

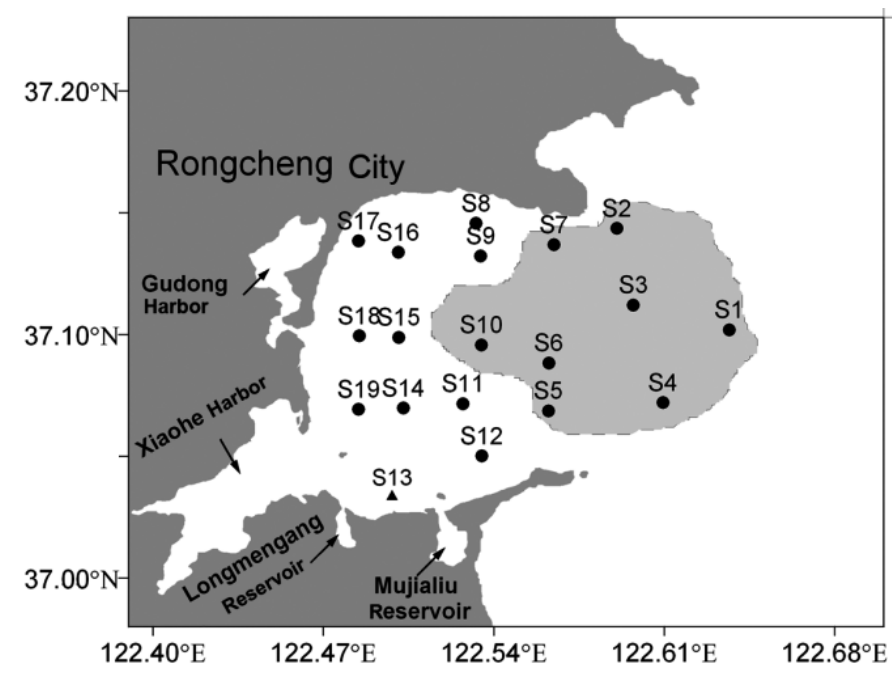

(1999). Seawater used for chl a analysis was filtered through GF/F filters (Whatman). Chl a was then measured using a Turner Design fluorometer (10-AU$005-\mathrm{CE}$ ) after extraction with $90 \%$ acetone at $-20^{\circ} \mathrm{C}$ for $24 \mathrm{~h}$ in the dark (Parsons et al. 1984). The results were calibrated using a pure chl a standard (Sigma).

\section{Enclosure experiments} pigmented nanoflagellates (PNF) were distinguished by their orange and red autofluorescence under blue light excitation (Tsai et al. 2010). Length and width were measured using Leica DM 4500 software. To obtain a reliable estimation of abundance, at least $100 \mathrm{NF}$ were counted per sample. In this study, NF were in the size range of $2-10 \mu m_{;}$NF of size range $10-20 \mu \mathrm{m}$ were not found in any samples.

\section{Flow cytometry analysis of bacteria}

Bacteria were enumerated by flow cytometry using a FACS Vantage SE system (Becton Dickinson) equipped with a water-cooled argon laser $(488 \mathrm{~nm}$, $1 \mathrm{~W}$, Coherent). Heterotrophic bacteria were stained with SYBR Green I (Molecular Probes) (final dilution: $10^{-4}, \mathrm{v} / \mathrm{v}$ ) and identified by their green fluorescence (Marie et al. 1997).

\section{Nutrients and chl a biomass}

The concentrations of dissolved inorganic nitrogen (DIN; sum of $\mathrm{NO}_{3}{ }^{-}, \mathrm{NO}_{2}{ }^{-}$and $\mathrm{NH}_{4}{ }^{+}$) and phosphate $\left(\mathrm{PO}_{4}{ }^{3-}\right)$ were measured using a Skalar SAN ${ }^{\text {lus }}$ autoanalyser, following the methods of Hansen \& Koroleff
Three transparent polyethylene bags, each filled with approximately $1000 \mathrm{l}$ of surface seawater, were used to establish enclosures at Stn S13 (Fig. 1) in June 2012. Bags were placed on rafts (with buoys), which provided buoyancy. The bags were suspended, and the seawater in the bags was naturally mixed by the wave and flow, thus the seawater in the bags could be considered to be as homogeneous as the surrounding water. The bags were washed 5 times with natural seawater to eliminate external contamination prior to the experiment. One bag containing merely natural seawater was used as the control. The second bag, into which 13 scallops Chlamys farreri (mean wet weight of $28.2 \pm 2.4 \mathrm{~g}$ ind. ${ }^{-1}$ ) with their original attaching plates were introduced, was set as the bivalve treatment. The third bag served as the macroalgae treatment, where $200 \mathrm{~g}$ (wet weight) of G. lemaneiformis was introduced. The biomass of bivalves and macroalgae used in the enclosure experiments was similar to the densities of local aquaculture practices. The bivalves and macroalgae were hung using nylon ropes to prevent them from touching the bottom and walls of the bags. During the experiments, bivalves and macroalgae were cultured in natural seawater 
without the artificial food input or nutrient addition. To prevent outside seawater from entering the bags, we set the upper edges of the mouth $\sim 20 \mathrm{~cm}$ above the sea surface level. The experiment lasted for $7 \mathrm{~d}$, and sampling was performed at approximately 10:00 h every day. During the experiment, mean temperature and salinity was $20.38 \pm 2.15^{\circ} \mathrm{C}$ and $31.20 \pm 0.16 \mathrm{psu}$, respectively. The NF, bacteria, chl $a$ and nutrient measurements were conducted as described in the previous 3 subsections.

\section{Statistical analysis}

Differences in physical (temperature), chemical (DIN and $\mathrm{PO}_{4}{ }^{3-}$ ) and biological values (chl $a$, bacteria, and NF) between the B-area and M-area were assessed using a $t$-test. One-way ANOVA and least significant difference (LSD) test for multiple comparisons were performed to evaluate the differences in NF or bacterial abundance among different seasons. Pearson correlation analysis was employed to analyse the relationships between all variables in the field survey. To reveal differences among different enclosures, all data from the enclosure experiments were analysed with repeated-measures ANOVA. All analyses were carried out using the statistical program SPSS 16.0, with a significance level of $5 \%$.

\section{RESULTS}

\section{Spatial variation of environmental factors and NF abundance over 4 seasons}

The distribution of salinity was relatively homogeneous in winter and spring in Sungo Bay, and salinity was $<31 \mathrm{psu}$ in spring. The salinity gradient was large in summer but small in autumn (Fig. 2A-D). However, a temperature gradient existed throughout the year. In spring and summer, temperature decreased from the inner bay to outer bay, while in autumn and winter, it increased from the inner to the outer bay (Fig. 2E-H). The gradient distribution of the chl a biomass appeared in the warm seasons and increased from the bay mouth to the bay head (Fig. 2J,K). In winter, chl a biomass was high in the bay mouth (Fig. 2L), while in spring high chl a biomass was observed in both the bay mouth and the bay head (Fig. 2I).

Total nanoflagellate (TNF) abundance ranged from $0.32 \times 10^{3}$ to $171.62 \times 10^{3}$ cells $\mathrm{ml}^{-1}$ during the study period. A gradient distribution of TNF appeared in the warm seasons but was relatively homogeneous in the cold seasons (winter and spring) (Fig. 3A-D). PNF contributed 41.50, 65.18, 65.96 and $43.02 \%$ of TNF abundance in spring, summer, autumn and winter, respectively. PNF and HNF distributions were similar to the distribution of TNF (Fig. 3E-L).

\section{Differences between B-area and M-area}

Water temperature was significantly different between the B-area and the M-area over the 4 seasons ( $\mathrm{p}<0.05, t$-test) (Table 1 ). No significant differences were observed regarding the other measured environmental factors (i.e. salinity, chl $a$, DIN and $\mathrm{PO}_{4}{ }^{3-}$ ) between the 2 areas in the cold seasons ( $\mathrm{p}>$ 0.05 , $t$-test) (Table 1). However, in the warm seasons, salinity was significantly lower in the B-area than in the M-area; the concentrations of nutrients (except for DIN in autumn) and chl a biomass were significantly higher in the B-area than in the M-area ( $\mathrm{p}<$ $0.05, t$-test) (Table 1). Bacterial abundance remained higher in the B-area than in the M-area throughout the year ( $p<0.05, t$-test) (Table 1$)$.

According to the presence or absence of pigments, NF were divided into HNF and PNF. The NF community was dominated by PNF in the warm seasons and HNF in the cold seasons (Fig. 4). The abundances of TNF, PNF and HNF were significantly higher in the $\mathrm{B}$-area than in the $\mathrm{M}$-area $(\mathrm{p}<0.05, t$-test) in the warm seasons, but were similar between the 2 areas during the cold seasons ( $p>0.05, t$-test) (Fig. 4). Size ranges of NF of $2-5 \mu \mathrm{m}$ and 5-10 $\mu \mathrm{m}$ were distinguished. NF of both size classes were more abundant in the B-area than in the M-area during the warm seasons (Fig. 5). Both the abundance of NF (TNF, HNF, PNF, 2-5 $\mu \mathrm{m}$ NF and 5-10 $\mu \mathrm{m} \mathrm{NF}$; Figs. 4 \& 5) and bacteria (Table 1) showed a significant ( $p<0.05)$ seasonal variation, with the lowest value in winter and highest value in summer.

\section{Variations in NF, nutrients, chl $a$ and bacteria in experimental enclosures}

DIN concentrations were not significantly different among the 3 enclosures (repeated-measures ANOVA, $\mathrm{p}>0.05$ ) (Fig. 6A). Compared with other enclosures, the concentration of $\mathrm{PO}_{4}{ }^{3-}$ was significant higher in the bivalve treatment (repeated-measures ANOVA, $\mathrm{p}<0.01$ ). However, no significant differences (repeated-measures ANOVA, p > 0.05) were detected between the macroalgae treatment and the control 


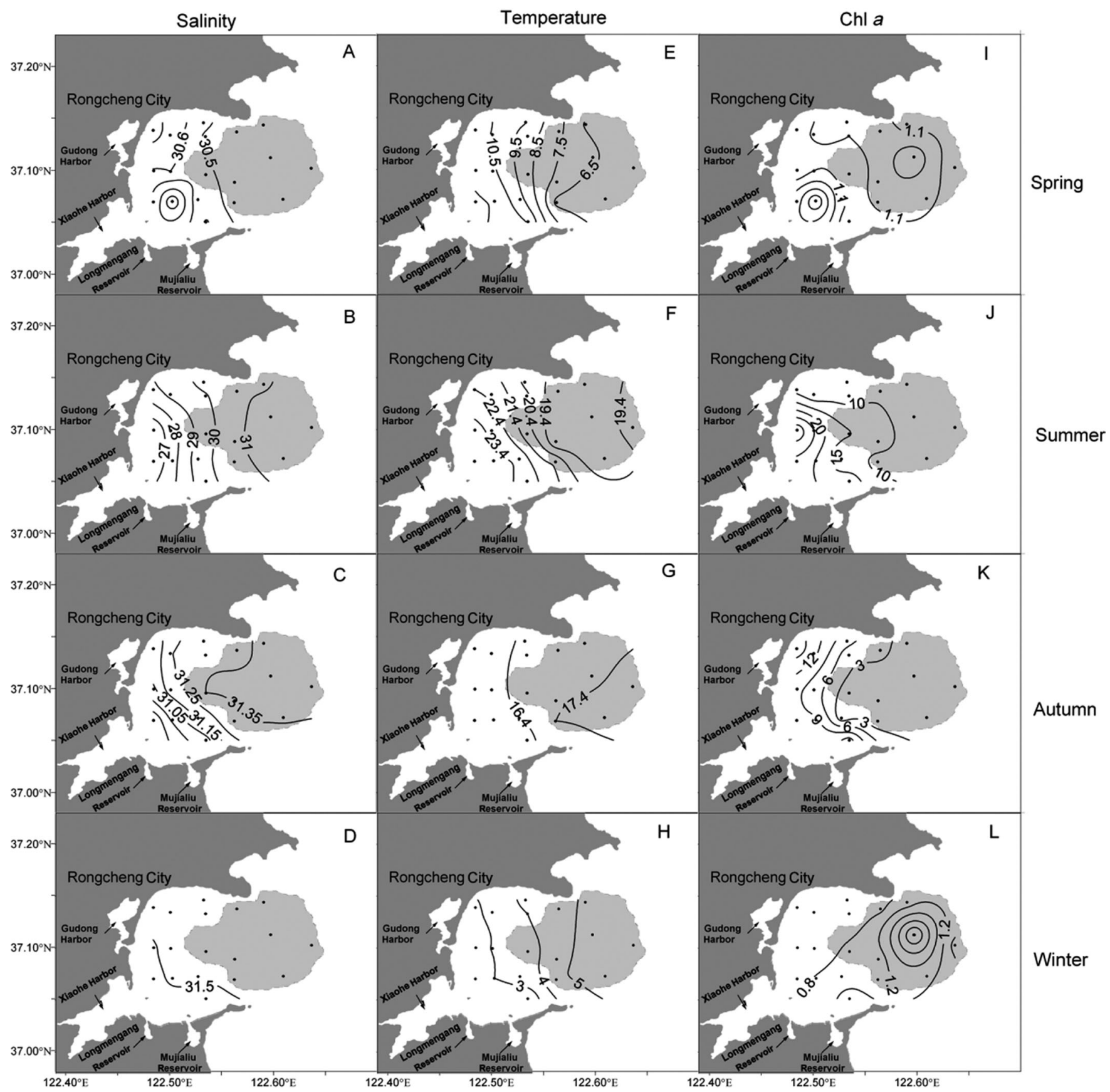

Fig. 2. Spatial variations in (A-D) salinity (psu), (E-H) temperature $\left({ }^{\circ} \mathrm{C}\right)$ and $(\mathrm{I}-\mathrm{L})$ chl a biomass $\left(\mu \mathrm{g} \mathrm{l}^{-1}\right)$ over 4 seasons. Sampling stations, M-area and B-area are marked as in Fig. 1

(Fig. 6B). The differences in chl a biomass were significant among the 3 enclosures (repeated-measures ANOVA, $\mathrm{p}<0.01$ ). Chl a biomass was significantly higher in the bivalve treatment than in the control, and was significantly lower in the macroalgae treatment than in the control (repeated-measures ANOVA, $\mathrm{p}<0.05$ ) (Fig. 7A).

Bacterial abundance was significantly higher in the bivalve treatment than in the other enclosures (repeated-measures ANOVA, $\mathrm{p}<0.01$ ) and increased steadily with time to 4.68 times the initial level. Though bacterial abundance was higher in the macroalgae treatment than in the control after Day 2, the differences between the macroalgae treatment and the control were not significant (repeated-measures ANOVA, p > 0.05) (Fig. 7B).

No significant differences in NF abundance (including TNF, HNF, PNF, 2-5 $\mu \mathrm{m} \mathrm{NF}$ and 5-10 $\mu \mathrm{m}$ 


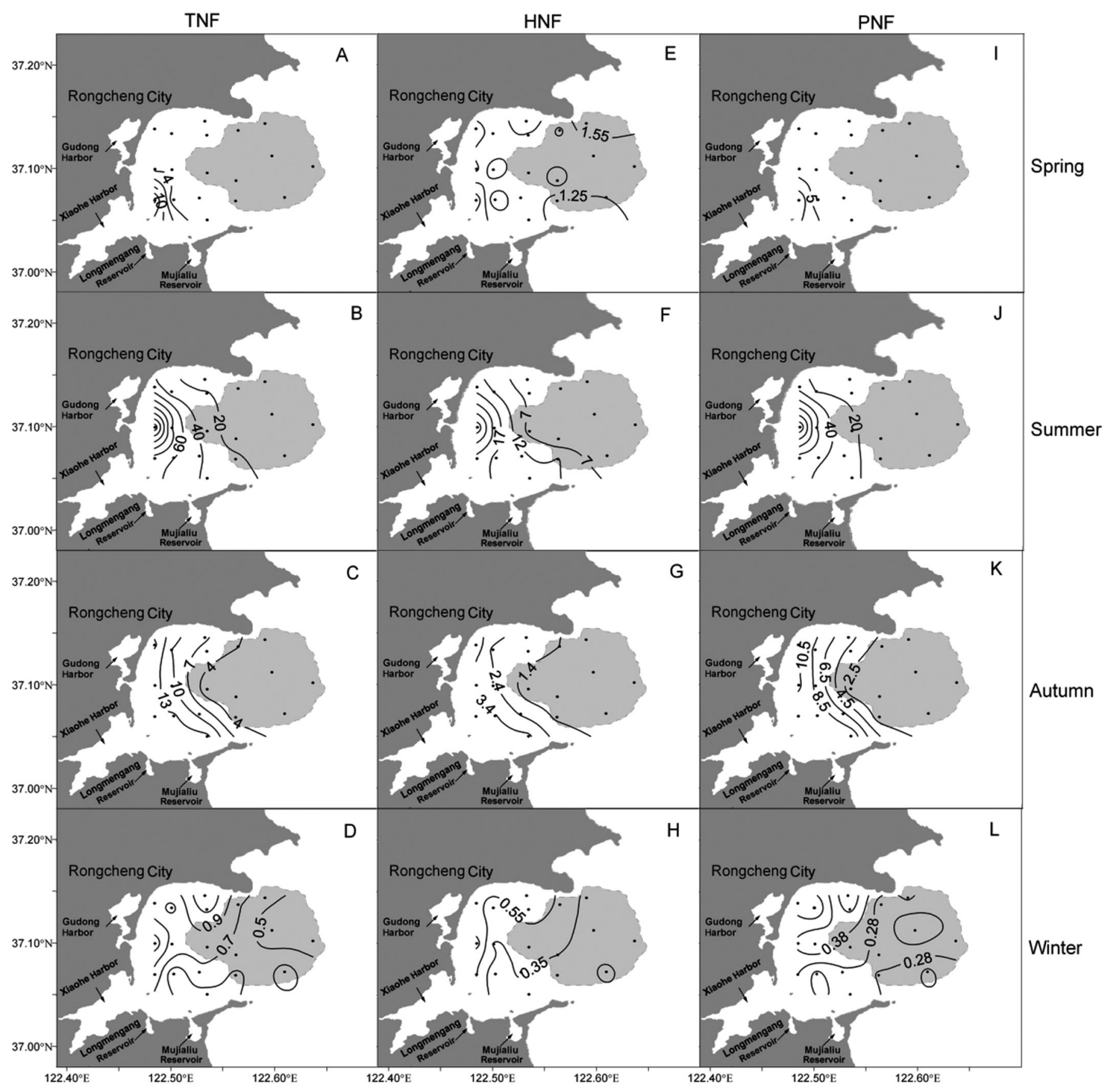

Fig. 3. Spatial variations in (A-D) total nanoflagellate (TNF) abundance, $(\mathrm{E}-\mathrm{H})$ heterotrophic nanoflagellate (HNF) abundance and (I-L) pigmented nanoflagellate (PNF) abundance (all: $\times 10^{3}$ cells $\mathrm{ml}^{-1}$ ) over 4 seasons. Sampling stations, M-area and B-area are marked as in Fig. 1

$\mathrm{NF}$ ) were detected among the 3 enclosures (repeated-measures ANOVA, $\mathrm{p}>0.05$ ). However, the effect of time on NF abundances was significant (Day $\times$ Treatment, $\mathrm{p}>0.05$ ). The abundance of TNF, HNF, PNF and 2-5 $\mu \mathrm{m}$ NF were clearly higher in the bivalve treatment than in the other 2 enclosures during the last $3 \mathrm{~d}$. However, no obvious differences in the 5-10 $\mu \mathrm{m} \mathrm{NF}$ were found among the 3 enclosures even during the last $3 \mathrm{~d}$, indicating that the increased abundance of NF in the bivalve treatment was the result of an increased abundance of 2-5 $\mu \mathrm{m}$ NF. No obvious differences were found with respect to the NF (TNF, HNF, PNF, 5-10 $\mu \mathrm{m}$ $\mathrm{NF}$ and 2-5 $\mu \mathrm{m}$ NF) abundance between the control and the macroalgae treatment in the last 3 d (Figs. 8 \& 9). 


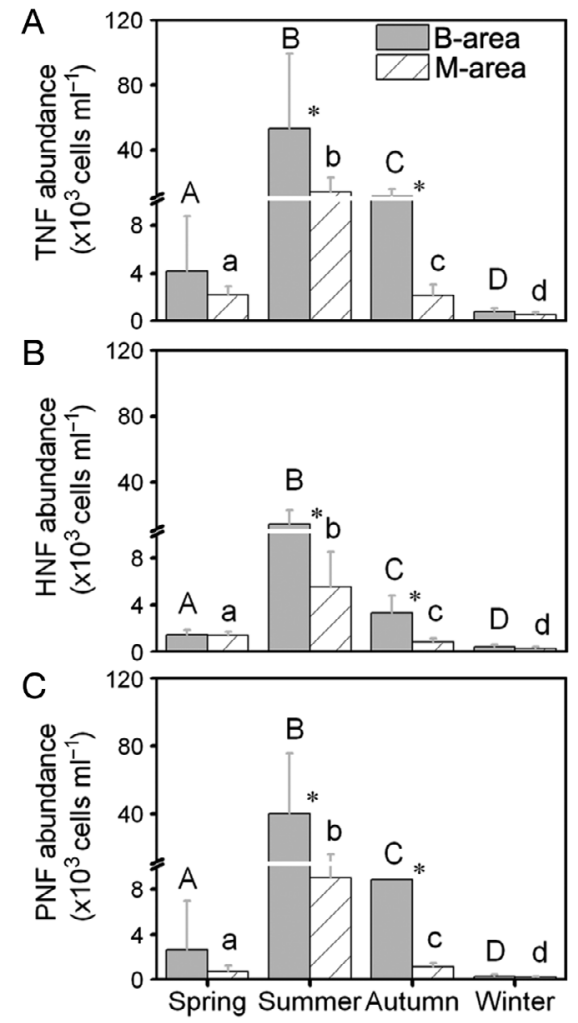

Fig. 4. Mean $(+\mathrm{SD})$ abundance of $(\mathrm{A})$ total nanoflagellate (TNF), (B) heterotrophic nanoflagellate (HNF) and (C) pigmented nanoflagellate (PNF) in the B-area and $\mathrm{M}$-area (see Fig. 1). ${ }^{*}$ Significant difference $(\mathrm{p}<0.05, t$-test) between the 2 areas in the same season. Different uppercase and lowercase letters indicate significant $(\mathrm{p}<0.05)$ differences among 4 seasons for B-area and $\mathrm{M}$-area, respectively
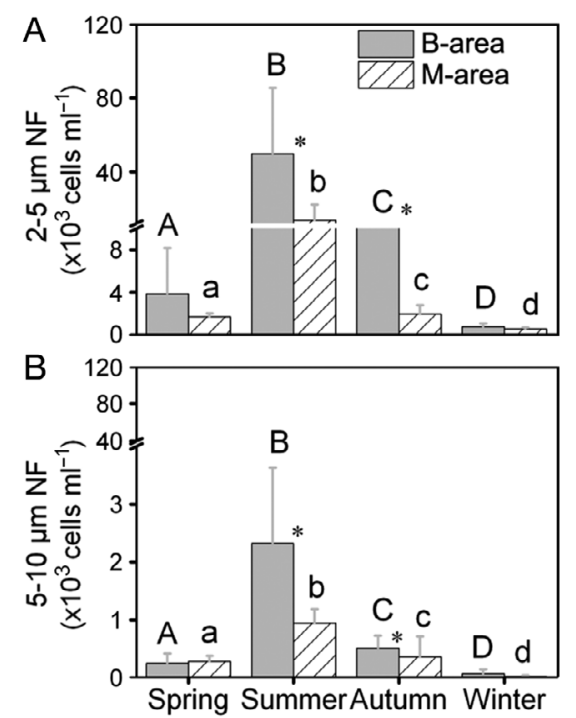

Fig. 5. Mean (+SD) abundance of (A) 2-5 $\mu \mathrm{m}$ nanoflagellates (NF) and (B) 5-10 $\mu \mathrm{m} \mathrm{NF}$ in the B-area and $\mathrm{M}$-area (see Fig. 1). ${ }^{*}$ Significant difference $(\mathrm{p}<0.05, t$-test) between the 2 areas in the same season. Different uppercase and lowercase letters indicate significant $(p<0.05)$ differences among 4 seasons for B-area and $\mathrm{M}$-area, respectively 

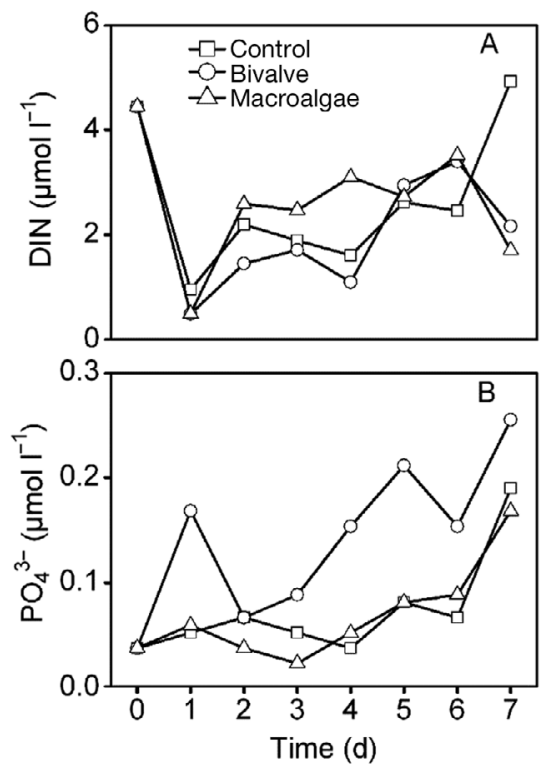

Fig. 6. Variations in concentrations of (A) dissolved inorganic nitrogen (DIN) and (B) $\mathrm{PO}_{4}{ }^{3-}$ in the enclosure experiments over time
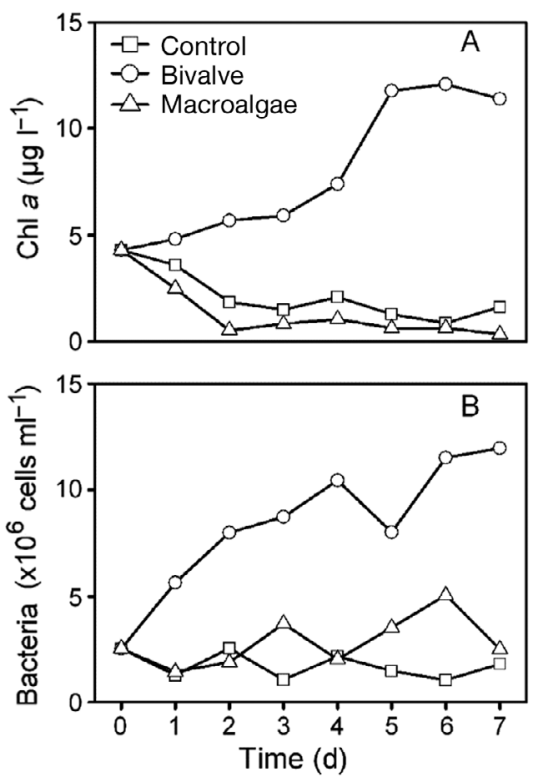

Fig. 7. Variations in (A) chl a biomass and (B) bacterial abundance in the enclosure experiments over time

\section{DISCUSSION}

In this study, a field survey was carried out to reveal relationships between NF and environmental factors; enclosure experiments in situ were conducted to study the effects of mariculture on NF. The aim was to assess the possible effects of environmental factors and mariculture on the spatial distribution of NF in Sungo Bay.
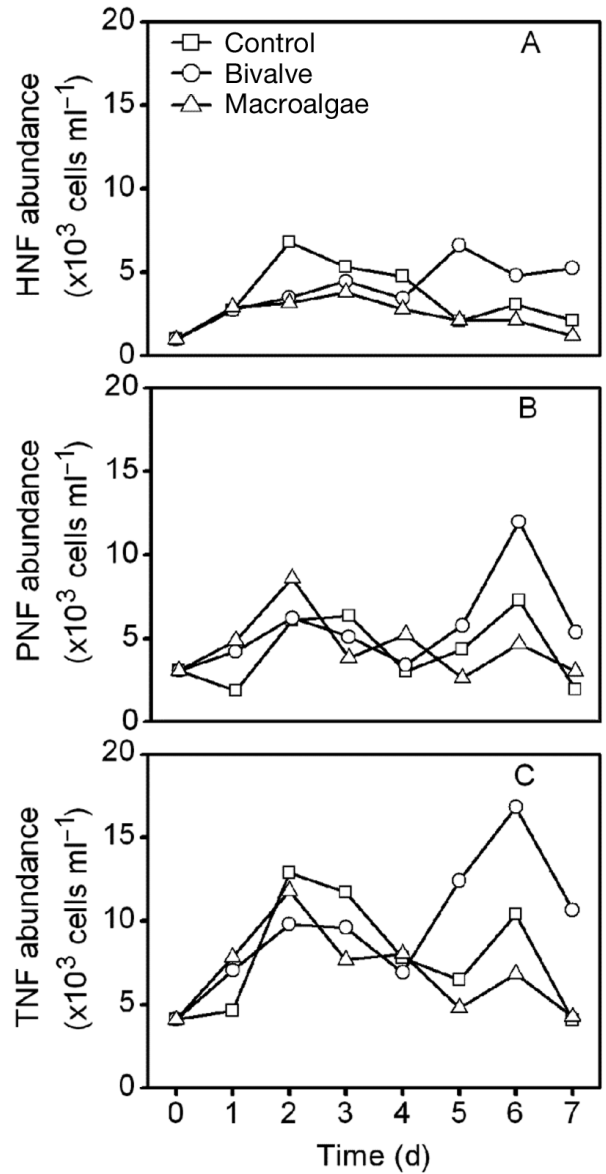

Fig. 8. Variations in abundance of (A) heterotrophic nanoflagellates (HNF), (B) pigmented nanoflagellates (PNF) and (C) total nanoflagellates (TNF) in the enclosure experiments over time

\section{Comparison with other bays in East Asia}

During the study period, NF abundance in Sungo Bay varied from $0.32 \times 10^{3}$ to $171.62 \times 10^{3}$ cells ml $^{-1}$ (Fig. 3A-D), which was within the typical range for NF in planktonic ecosystems $\left(10^{2}-10^{5}\right.$ cells $\mathrm{ml}^{-1}$ ) (Lee \& Patterson 2002, Huang et al. 2008). However, NF were more abundant in Sungo Bay than in the open waters of the Yellow Sea, except in winter, when the water temperature was lower in Sungo Bay than in the open water (Lin 2012). Interestingly, although Sungo Bay is a phosphorus (P)-deficient system (Sun et al. 2007), NF abundance levels in Sungo Bay appeared to be higher than in other eutrophic bays in East Asia, except for Funka Bay, which was sampled during a spring pre-bloom period for phytoplankton (Table 2) (Lee et al. 2001, Choi et al. 2003, Kamiyama 2004, Yang et al. 2008). The higher abundance of NF in Sungo Bay may relate to both the specific environmental conditions and mariculture in the bay. 
Table 2. Comparison of nanoflagellate abundances in Sungo Bay with those reported in other bays. HNF: heterotrophic nanoflagellates, PNF: pigmented nanoflagellates

\begin{tabular}{|c|c|c|c|c|c|}
\hline Study area & Location & Study period & $\begin{array}{l}\text { Nanofla- } \\
\text { gellates }\end{array}$ & $\begin{array}{c}\text { Abundance } \\
\left(\times 10^{3} \text { cells } \mathrm{ml}^{-1}\right)\end{array}$ & Reference \\
\hline Gyeonggi Bay & Middle northern region of Yellow Sea, Korea & Jan 1997-Dec 1999 & HNF & 1.94 & Yang et al. (2008) \\
\hline Masan Bay & Southern coast of Korea & Aug 1999 & HNF & $1.04 \pm 0.72$ & Choi et al. (2003) \\
\hline Funka Bay & SW of Hokkaido, Japan & Mar 1999 & HNF & 2.86 & Lee et al. (2001) \\
\hline Hiroshima Bay & Seto Inland Sea, Japan & Jun-Jul 1995 & HNF & $0.52-11.06$ & Kamiyama (2004) \\
\hline \multirow[t]{2}{*}{ Sungo Bay } & NW coast of Yellow Sea, China & Apr 2011-Jan 2012 & HNF & $3.77 \pm 6.00$ & This study \\
\hline & & & PNF & $8.73 \pm 19.46$ & This study \\
\hline
\end{tabular}

\section{Temperature limitation in winter}

Water temperature characterised the seasonal pattern of NF by affecting physiological processes as well as food density (Weisse 1991, 1997, Hansen \& Christoffersen 1995, Zhao et al. 2003). When the abundance of bacteria approaches a threshold of $3 \times$ $10^{5}$ cells $\mathrm{ml}^{-1}$, the effective grazing of NF is limited (Berninger et al. 1991). In winter, both in the B-area $\left(3.28 \times 10^{5} \pm 0.63 \times 10^{5}\right.$ cells $\left.\mathrm{ml}^{-1}\right)$ and M-area $(2.67 \times$ $10^{5} \pm 0.46 \times 10^{5}$ cells $\mathrm{ml}^{-1}$ ), bacterial abundance was near the threshold density of effective grazing for NF, and thus, NF in both areas likely faced a shortage of food. Therefore, we speculate that the lack of a significant difference in NF abundance between the
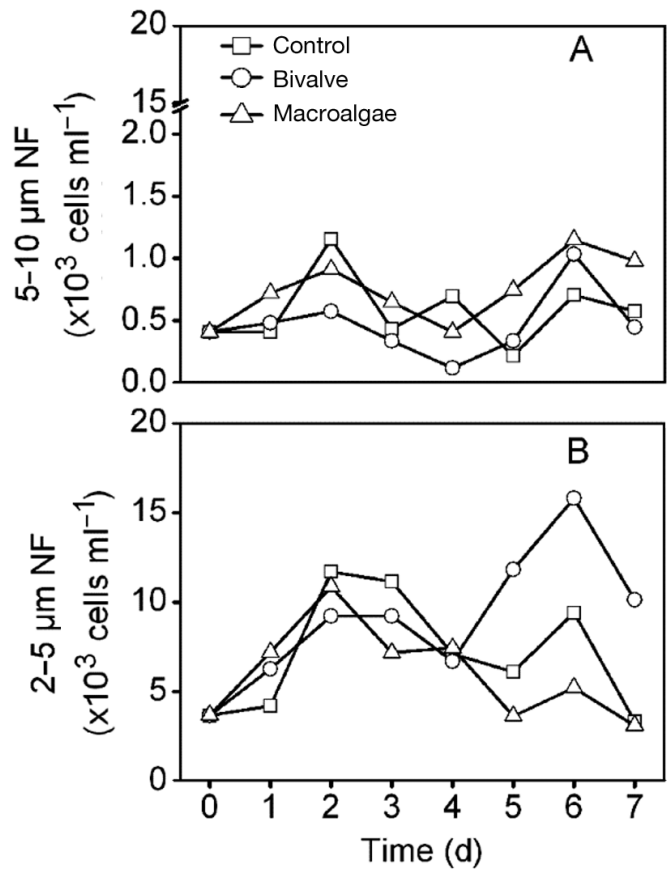

Fig. 9. Variations in abundance of (A) 5-10 $\mu \mathrm{m}$ nanoflagellates (NF) and (B) 2-5 $\mathrm{m}$ NF in the enclosure experiments over time
$\mathrm{B}$-area and $\mathrm{M}$-area in winter is probably due to the low temperature $\left(<5^{\circ} \mathrm{C}\right.$ average $)$, which limits the growth of bacteria (Tsai et al. 2005).

\section{Effects of freshwater input on distribution of NF}

Together with water temperature, salinity is also used as an indicator of different water masses (with different nutrient levels) when analysing the spatial distribution of NF (Sherr et al. 1988, Andersson et al. 1994, Vázquez-Domínguez et al. 2012, Lin et al. 2014). However, Sungo Bay is a shallow bay with an average depth of $7.5 \mathrm{~m}$ (Zhang et al. 2009). Surface water temperature in the shallow system is mainly controlled by air temperature and solar heat gain rather than water mass interactions. Therefore, we used salinity as the only indicator of freshwater discharge in this study. Freshwater influenced Sungo Bay mainly in the warm seasons (Fig. 2A-D). Salinity in the spring was $<31$ psu (Fig. 2A), most likely due to several rain events prior to sampling.

Sungo Bay is a P-deficient and nitrogen-eutrophic system (Sun et al. 2007), where the growth of osmotrophic organisms (bacteria and autotrophic PNF) may depend on $\mathrm{P}$ concentration rather than DIN. Both in summer and autumn, Sungo Bay experienced a freshwater influx (Fig. 2B,C), and the abundance of both NF and bacteria were negatively related to salinity (Table 3). Freshwater may bring a certain amount of terrestrial nutrients, which likely resulted in higher $\mathrm{PO}_{4}{ }^{3-}$ concentrations in the B-area (Table 1). It has been reported that higher nutrient supplies might result in a higher abundance of NF (Safi \& Hall 1997, Huang et al. 2008, Tsai et al. 2010). Therefore, freshwater input in the warm seasons may have caused higher TNF abundance in the B-area than in the M-area (Fig. 4).

However, the correlation between salinity and nutrients was not significant (Table 3), which was likely due to the patchy distribution of bivalves in the 
Table 3. Correlations between total nanoflagellate (TNF) abundance, bacterial abundance and salinity and other factors in Sungo Bay in the 4 seasons. DIN: dissolved inorganic nitrogen. Correlation is significant (in bold) at *the 0.05 level (2-tailed) or ${ }^{* *}$ the 0.01 level (2-tailed)

\begin{tabular}{|c|c|c|c|c|c|c|}
\hline & & Bacteria & Chl a & $\mathrm{PO}_{4}{ }^{3-}$ & DIN & Salinity \\
\hline Spring & $\begin{array}{c}\text { TNF } \\
\text { Bacteria } \\
\text { Salinity }\end{array}$ & $\begin{array}{l}0.405 \\
- \\
\mathbf{0 . 4 8 3}^{*}\end{array}$ & $\begin{array}{l}\mathbf{0 . 6 1 1}^{\text {*** }} \\
0.186 \\
0.086\end{array}$ & $\begin{array}{r}0.224 \\
-0.057 \\
-0.013\end{array}$ & $\begin{array}{l}-0.169 \\
-0.153 \\
-0.295\end{array}$ & $\begin{array}{l}0.125 \\
\mathbf{0 . 4 8 3}^{*} \\
-\end{array}$ \\
\hline Summer & $\begin{array}{c}\text { TNF } \\
\text { Bacteria } \\
\text { Salinity }\end{array}$ & $\begin{array}{c}0.645^{* *} \\
-\overline{0.829 * *}\end{array}$ & $\begin{array}{r}0.681^{* *} \\
0.729^{* *} \\
-0.859^{* *}\end{array}$ & $\begin{array}{r}-0.061 \\
0.032 \\
-0.005\end{array}$ & $\begin{array}{r}0.382 \\
0.445 \\
-0.424\end{array}$ & $\begin{array}{l}-0.784^{* *} \\
-0.829^{* *} \\
-\end{array}$ \\
\hline Autumn & $\begin{array}{c}\text { TNF } \\
\text { Bacteria } \\
\text { Salinity }\end{array}$ & $\begin{array}{l}0.967^{* *} \\
- \\
-0.944^{* *}\end{array}$ & $\begin{array}{r}0.929^{* *} \\
0.940^{* *} \\
-0.805^{* *}\end{array}$ & $\begin{array}{r}0.351 \\
0.371 \\
-0.290\end{array}$ & $\begin{array}{r}-0.270 \\
-0.228 \\
0.169\end{array}$ & $\begin{array}{l}-0.893^{* *} \\
-0.944^{* *} \\
-\end{array}$ \\
\hline Winter & $\begin{array}{c}\text { TNF } \\
\text { Bacteria } \\
\text { Salinity }\end{array}$ & $\begin{array}{c}-0.106 \\
- \\
-0.216\end{array}$ & $\begin{array}{r}0.110 \\
-0.148 \\
-0.001\end{array}$ & $\begin{array}{r}-0.073 \\
-0.216 \\
0.038\end{array}$ & $\begin{array}{r}-0.142 \\
-0.234 \\
0.300\end{array}$ & $\begin{array}{l}0.038 \\
-0.216 \\
-\end{array}$ \\
\hline
\end{tabular}

bay. Nutrients released by the bivalves might lower the correlation between salinity and nutrient concentrations. The correlations between bacteria and NF abundances and nutrient concentrations were also not significant (Table 3 ), likely because the bivalves' grazing may have had effects on the abundance of bacteria and NF. In sum, the spatial variations of the NF in Sungo Bay could not be only attributed to the influence of freshwater discharge.

\section{Effects of nutrient release and grazing of bivalves on NF}

In fact, the nutrient release by bivalves plays an important role in aquaculture areas (Carlsson et al. 2012, Cranford et al. 2012) and has been used to explain the predominance of bacteria, autotrophic flagellates and picoeukaryotes in areas of intense bivalve farming (Dupuy et al. 2000a). Bacterial growth is known to be stimulated by phosphate addition when ambient phosphate concentration drops $<0.1 \mu \mathrm{M}$ (Morris \& Lewis 1992, Carlsson \& Caron 2001). With bacterivores and autotrophic PNF being the predominant assemblages in the $2-5 \mu \mathrm{m} \mathrm{NF}$ (Unrein et al. 2007, Jürgens et al. 2008, Tsai et al. 2011), nutrient excretion (mainly P) by bivalves may increase the abundance of 2-5 $\mu \mathrm{m}$ NF either directly by increasing the abundance of autotrophic NF or indirectly by increasing the prey of bacterivorous NF. The abundance of $2-5 \mu \mathrm{m}$ NF contributed $\sim 90 \%$ of the TNF abundance (data not shown) in our study and bivalve cultivation substantially increased the concentration of $\mathrm{PO}_{4}{ }^{3-}$ (Fig. 6B). Thus, we suggest that the release of $\mathrm{P}$ by bivalves may have caused the ele- vated abundance of TNF observed during the last $3 \mathrm{~d}$ of our enclosure experiment.

Based on microscopic observations, $\sim 7 \mu \mathrm{m}$ NF dominated in 5-10 $\mu \mathrm{m} \mathrm{NF}$, and $>3 \mu \mathrm{m}$ NF dominated in $2-5 \mu \mathrm{m}$ NF in this study. The size ratio between protist predators and their optimal prey is suggested to be $3: 1$ (Hansen et al. 1994). Therefore, the main predator of 2-5 $\mu \mathrm{m}$ NF may be a protist $>10 \mu \mathrm{m}$ in size, and the main predator of 5-10 $\mu \mathrm{m}$ NF may be a protist $>20 \mu \mathrm{m}$.

Bivalves cannot efficiently filter picoplankton (Kach \& Ward 2008), and their retention efficiency decreases with decreasing particle size (Charles et al. 1999). Further, small flagellates $(<5 \mu \mathrm{m})$ are poorly retained compared to protists with a size $>5 \mu \mathrm{m}$ (Dupuy et al. 2000b). In Sungo Bay, the retention rate of scallops Chlamys farreri was $8 \%$ on $2 \mu \mathrm{m}$ particles and $45 \%$ on $8 \mu \mathrm{m}$ particles, and the retention rate dropped with decreasing particle size (Zhang et al. 2010). Therefore, the feeding selectivity of the bivalves probably relieved the grazing pressure of $<5 \mu \mathrm{m} N F$. This may explain why the abundance of $2-5 \mu \mathrm{m}$ NF increased in the bivalve enclosure experiment, while 5-10 $\mu \mathrm{m}$ NF remained relatively stable over time in the same enclosure (Fig. 9).

Though no significant differences in NF abundance were found among the 3 enclosures (repeatedmeasures ANOVA, $p>0.05$ ), NF abundance in the bivalve treatment increased during the last $3 \mathrm{~d}$. The enclosure experiments were maintained for only $7 \mathrm{~d}$, but our results are similar to a 1 yr long experiment conducted by Dupuy et al. (2000a) in an oyster farming pond, where $<5 \mu \mathrm{m}$ NF developed at a more intense rate than in the control pond (without oysters). Therefore, it would be reasonable to expect that NF abundance might remain higher in the bivalve enclosure than other enclosures for a longer period of time.

The optimal temperature for $C$. farreri is between 19 and $22^{\circ} \mathrm{C}$, and the scallop stops growing at around $4^{\circ} \mathrm{C}$ (Yang et al. 1999, Zhang et al. 2004). Though the enclosure experiments were conducted only in summer, it would be reasonable to expect that the feeding and P-release of the bivalves would be significantly greater in summer and autumn $\left(15.5-23.8^{\circ} \mathrm{C}\right)$ than in spring and winter $(2.2-$ $\left.10.6^{\circ} \mathrm{C}\right)$. 


\section{Effects of macroalgae on NF}

Bacteria and macroalgae competed with phytoplankton for nutrients (Sfriso \& Pavoni 1994, Pedersen \& Borum 1996, Passow et al. 2007, Thingstad et al. 2007, Thingstad \& Cuevas 2010). The introduction of macroalgae enhanced the competition for $\mathrm{P}$, and this was confirmed by the decrease in chl a biomass in the macroalgae enclosure (Fig. 7A). The competition for limited $\mathrm{P}$ among different taxonomic groups may limit the use of DIN. Though the DOC released by macroalgae is available for bacterial growth (Hatcher et al. 1977, Pregnall 1983), the P deficiency may limit the increase in bacterial abundance even in the presence of excess DOC. The P deficiency and the insignificant increase of bacteria may explain the lack of a significant difference in NF abundance between the macroalgae treatment and the control. Overall, at least in summer, NF abundance should be higher in the B-area than in the $\mathrm{M}$-area if the impacts of mariculture are considered individually.

In conclusion, both freshwater input and mariculture of bivalves and magroalgae are likely important factors influencing the spatial distribution of NF in warm seasons in Sungo Bay.

Acknowledgements. This study was supported by the National Key Programme for Developing Basic Sciences of China (No. 2011CB409804) and National Natural Science Foundation of China (No. 41376131). We thank Kuo-Ping Chiang (National Taiwan Ocean University) for his useful suggestions and comments. We also express our deep gratitude to Xiao Ma for her hard work in data input.

\section{LITERATURE CITED}

Andersson A, Haecky P, Hagström Å (1994) Effect of temperature and light on the growth of micro-, nano- and pico-plankton: impact on algal succession. Mar Biol 120: 511-520

Armstrong E, Rogerson A, Leftley JW (2000) Utilisation of seaweed carbon by three surface-associated heterotrophic protists, Stereomyxa ramosa, Nitzschia alba and Labyrinthula sp. Aquat Microb Ecol 21:49-57

Bacher C, Grant J, Hawkins AJS, Fang J, Zhu M, Besnard M (2003) Modelling the effect of food depletion on scallop growth in Sungo Bay (China). Aquat Living Resour 16: 10-24

Berninger UG, Finlay BJ, Kuuppo-Leinikki P (1991) Protozoan control of bacterial abundances in freshwater. Limnol Oceanogr 36:139-147

Bręk-Laitinen G, Ojala A (2011) Grazing of heterotrophic nanoflagellates on the eukaryotic picoautotroph Choricystis sp. Aquat Microb Ecol 62:49-59

Calbet A, Landry MR, Nunnery S (2001) Bacteria-flagellate interactions in the microbial food web of the oligotrophic subtropical North Pacific. Aquat Microb Ecol 23:283-292
Carlsson P, Caron DA (2001) Seasonal variation of phosphorus limitation of bacterial growth in a small lake. Limnol Oceanogr 46:108-120

> Carlsson MS, Engström P, Lindahl O, Ljungqvist L, Petersen JK, Svanberg L, Holmer M (2012) Effects of mussel farms on the benthic nitrogen cycle on the Swedish west coast. Aquacult Environ Interact 2:177-191

Chan YF, Tsai AY, Chiang KP, Hsieh C (2009) Pigmented nanoflagellates grazing on Synechococcus: seasonal variations and effect of flagellate size in the coastal ecosystem of subtropical western Pacific. Microb Ecol 58:548-557

> Charles F, Amouroux JM, Gremare A (1999) Comparative study of the utilization of bacteria and microalgae by the suspension-feeding bivalve: Callista chione. J Mar Biol Assoc UK 79:577-584

Choi DH, Hwang CY, Cho BC (2003) Comparison of virusand bacterivory-induced bacterial mortality in the eutrophic Masan Bay, Korea. Aquat Microb Ecol 30:117-125

Christaki U, Vázquez-Domínguez E, Courties C, Lebaron P (2005) Grazing impact of different heterotrophic nanoflagellates on eukaryotic (Ostreococcus tauri) and prokaryotic picoautotrophs (Prochlorococcus and SynechoCoccus). Environ Microbiol 7:1200-1210

Cranford PJ, Kamermans P, Krause G, Mazurié J and others (2012) An ecosystem-based approach and management framework for the integrated evaluation of bivalve aquaculture impacts. Aquacult Environ Interact 2: 193-213

Dupuy C, Le Gall S, Hartmann HJ, Bréret M (1999) Retention of ciliates and flagellates by the oyster Crassostrea gigas in French Atlantic coastal ponds: protists as a trophic link between bacterioplankton and benthic suspension-feeders. Mar Ecol Prog Ser 177:165-175

Dupuy C, Pastoureaud A, Ryckaert M, Sauriau PG, Montanié H (2000a) Impact of the oyster Crassostrea gigas on a microbial community in Atlantic coastal ponds near La Rochelle. Aquat Microb Ecol 22:227-242

> Dupuy C, Vaquer A, Lam-Höai T, Rougier C and others (2000b) Feeding rate of the oyster Crassostrea gigas in a natural planktonic community of the Mediterranean Thau Lagoon. Mar Ecol Prog Ser 205:171-184

> Dupuy C, Ryckaert M, Le Gall S, Hartmann H (2007) Seasonal variations in planktonic community structure and production in an Atlantic coastal pond: the importance of nanoflagellates. Microb Ecol 53:537-548

Fang J, Sun H, Yan J, Kuang S, Li F, Newkirk GF, Grant J (1996) Polyculture of scallop Chlamys farreri and kelp Laminaria japonica in Sungo Bay. Chin J Oceanol Limnol 14:322-329

> Granda AP, Anadón RA (2008) The annual cycle of nanoflagellates in the Central Cantabrian Sea (Bay of Biscay). J Mar Syst 72:298-308

> Hansen B, Christoffersen K (1995) Specific growth rates of heterotrophic plankton organisms in a eutrophic lake during a spring bloom. J Plankton Res 17:413-430

Hansen HP, Koroleff F (1999) Determination of nutrients. In: Grasshoff K, Kremling K, Ehrhardt M (eds) Methods of seawater analysis, 3rd edn. Wiley-VCH, Weinheim, p 162-226

Hansen B, Bjørnsen PK, Hansen PJ (1994) The size ratio between planktonic predators and their prey. Limnol Oceanogr 39:395-403

Hatcher B, Chapman AO, Mann K (1977) An annual carbon budget for the kelp Laminaria longicruris. Mar Biol 44: 85-96 
Huang B, Lan W, Cao Z, Dai M, Huang L, Jiao N, Hong H (2008) Spatial and temporal distribution of nanoflagellates in the northern South China Sea. Hydrobiologia 605:143-157

Jürgens K, Massana R, Kirchman D (2008) Protist grazing on marine bacterioplankon. In: Kirchman DL (eds) Microbial ecology of the oceans, 2nd edn. Wiley-Liss, New York, NY, p 383-442

Kach DJ, Ward JE (2008) The role of marine aggregates in the ingestion of picoplankton-size particles by suspension-feeding molluscs. Mar Biol 153:797-805

Kamiyama T (2004) The microbial loop in a eutrophic bay and its contribution to bivalve aquaculture. Bull Fish Res Agency (Jpn) (Suppl 1):41-50

Kong F, Yu R, Zhang Q, Wang Y, Yan T, Zhou M (2012) Primary analyses on the causative species of a bloom in the Sanggou Bay. Mar Environ Sci 31:824-829 (in Chinese with English abstract)

Kreeger DA, Newell RIE (1996) Ingestion and assimilation of carbon from cellulolytic bacteria and heterotrophic flagellates by the mussels Geukensia demissa and Mytilus edulis (Bivalvia, Mollusca). Aquat Microb Ecol 11:205-214

Kuuppo P (1994) Annual variation in the abundance and size of heterotrophic nanoflagellates on the SW coast of Finland, the Baltic Sea. J Plankton Res 16:1525-1542

> Lee W, Patterson D (2002) Abundance and biomass of heterotrophic flagellates, and factors controlling their abundance and distribution in sediments of Botany Bay. Microb Ecol 43:467-481

> Lee CW, Kudo I, Morishita H, Yanada M, Maita Y (2001) Examining the relationship between bacteria and heterotrophic nanoflagellates in Funka Bay (Japan) using the size-fractionation method. Aquat Ecol 35:1-8

Le Gall S, Hassen MB, Le Gall P (1997) Ingestion of a bacterivorous ciliate by the oyster Crassostrea gigas: protozoa as a trophic link between picoplankton and benthic suspension-feeders. Mar Ecol Prog Ser 152:301-306

Lin S (2012) Ecological studies on the nanoflagellates in the Yellow Sea and East China Sea. PhD dissertation, Xiamen University (in Chinese with English abstract)

> Lin S, Huang L, Lu J (2014) Weak coupling between heterotrophic nanoflagellates and bacteria in the Yellow Sea Cold Water Mass area. Acta Oceanol Sin 33:125-132

Lucas MI, Newell RC, Velimirov B (1981) Heterotrophic utilisation of mucilage released during fragmentation of kelp (Ecklonia maxima and Laminaria pallida). II. Differential utilisation of dissolved organic components from kelp mucilage. Mar Ecol Prog Ser 4:43-55

Mao Y, Zhou Y, Yang H, Wang R (2006) Seasonal variation in metabolism of cultured pacific oyster Crassostrea gigas in Sanggou Bay, China. Aquaculture 253:322-333

Marie D, Partensky F, Jacquet S, Vaulot D (1997) Enumeration and cell cycle analysis of natural populations of marine picoplankton by flow cytometry using the nucleic acid stain SYBR Green I. Appl Environ Microbiol 63: 186-193

McKee MP, Ward JE, MacDonald BA, Holohan BA (2005) Production of transparent exopolymer particles (TEP) by the eastern oyster Crassostrea virginica. Mar Ecol Prog Ser 288:141-149

> Morris DP, Lewis WM (1992) Nutrient limitation of bacterioplankton growth in Lake Dillon, Colorado. Limnol Oceanogr 37:1179-1192

> Nunes J, Ferreira J, Gazeau F, Lencart-Silva J, Zhang X, Zhu M, Fang J (2003) A model for sustainable manage- ment of shellfish polyculture in coastal bays. Aquaculture 219:257-277

Parsons TR, Maita Y, Lalli CM (1984) A manual of chemical and biological methods for seawater analysis. Pergamon Press, Oxford

Passow U, De La Rocha CL, Arnosti C, Grossart HP, Murray AE, Engel A (2007) Microbial dynamics in autotrophic and heterotrophic seawater mesocosms. I. Effect of phytoplankton on the microbial loop. Aquat Microb Ecol 49:109-121

Pedersen MF, Borum J (1996) Nutrient control of algal growth in estuarine waters. Nutrient limitation and the importance of nitrogen requirements and nitrogen storage among phytoplankton and species of macroalgae. Mar Ecol Prog Ser 142:261-272

Pregnall A (1983) Release of dissolved organic carbon from the estuarine intertidal macroalga Enteromorpha prolifera. Mar Biol 73:37-42

Safi KA, Hall JA (1997) Factors influencing autotrophic and heterotrophic nanoflagellate abundance in five water masses surrounding New Zealand. N Z J Mar Freshw Res 31:51-60

Sanders RW, Berninger UG, Lim EL, Kemp PF, Caron DA (2000) Heterotrophic and mixotrophic nanoplankton predation on picoplankton in the Sargasso Sea and on Georges Bank. Mar Ecol Prog Ser 192:103-118

Sfriso A, Pavoni B (1994) Macroalgae and phytoplankton competition in the central Venice lagoon. Environ Technol 15:1-14

Sherr EB (1988) Direct use of high molecular weight polysaccharide by heterotrophic flagellates. Nature 335: 348-351

> Sherr BF, Sherr EB, Rassoulzadegan F (1988) Rates of digestion of bacteria by marine phagotrophic protozoa: temperature dependence. Appl Environ Microbiol 54: 1091-1095

> Sieburth JMN (1969) Studies on algal substances in the sea. III. The production of extracellular organic matter by littoral marine algae. J Exp Mar Biol Ecol 3:290-309

Sun P, Zhang Z, Hao L, Wang B, Wang Z (2007) Analysis of nutrient distributions and potential eutrophication in seawater of the Sangou Bay. Adv Mar Sci 25:436-455 (in Chinese with English abstract)

Thingstad TF, Cuevas LA (2010) Nutrient pathways through the microbial food web: principles and predictability discussed, based on five different experiments. Aquat Microb Ecol 61:249-260

> Thingstad TF, Havskum H, Zweifel UL, Berdalet E and others (2007) Ability of a 'minimum' microbial food web model to reproduce response patterns observed in enclosures manipulated with $\mathrm{N}$ and $\mathrm{P}$, glucose, and Si. J Mar Syst 64:15-34

Tsai AY, Chiang KP, Chang J, Gong GC (2005) Seasonal diel variations of picoplankton and nanoplankton in a subtropical western Pacific coastal ecosystem. Limnol Oceanogr 50:1221-1231

Tsai AY, Gong GC, Sanders RW, Wang CJ, Chiang KP (2010) The impact of the Changjiang River plume extension on the nanoflagellate community in the East China Sea. Estuar Coast Shelf Sci 89:21-30

- Tsai AY, Gong GC, Sanders RW, Chen WH, Chao CF, Chiang KP (2011) Importance of bacterivory by pigmented and heterotrophic nanoflagellates during the warm season in a subtropical western Pacific coastal ecosystem. Aquat Microb Ecol 63:9-18 
Unrein F, Massana R, Alonso-Sáez L, Gasol JM (2007) Significant year-round effect of small mixotrophic flagellates on bacterioplankton in an oligotrophic coastal system. Limnol Oceanogr 52:456-469

Vázquez-Domínguez E, Vaqué D, Gasol JM (2012) Temperature effects on the heterotrophic bacteria, heterotrophic nanoflagellates, and microbial top predators of the NW Mediterranean. Aquat Microb Ecol 67:107-121

Weisse T (1991) The annual cycle of heterotrophic freshwater nanoflagellates: role of bottom-up versus topdown control. J Plankton Res 13:167-185

> Weisse T (1997) Growth and production of heterotrophic nanoflagellates in a meso-eutrophic lake. J Plankton Res 19:703-722

Yang HS, Zhang T, Wang J, Wang P, He YC, Zhang FS (1999) Growth characteristics of Chlamys farreri and its relation with environmental factors in intensive raft-culture areas of Sishiliwan bay, Yantai. J Shellfish Res 18:71-76

Yang EJ, Choi JK, Hyun JH (2008) Seasonal variation in the community and size structure of nano- and microzooplankton in Gyeonggi Bay, Yellow Sea. Estuar Coast

Editorial responsibility: Gianluca Sara,

Palermo, Italy
Shelf Sci 77:320-330

Zhang ZH, Fang JG, Hawkins AJS, Pascoe PL (2004) The effect of temperature on clearance rate and oxygen consumption of scallops, Chlamys farreri. J Shellfish Res 23: 715-721

Zhang J, Hansen PK, Fang J, Wang W, Jiang Z (2009) Assessment of the local environmental impact of intensive marine shellfish and seaweed farming - application of the MOM system in the Sungo Bay, China. Aquaculture 287:304-310

Zhang J, Fang J, Liang X (2010) Variations in retention efficiency of bivalves to different concentrations and organic content of suspended particles. Chin J Oceanol Limnol 28:10-17

Zhao J, Zhou SL, Sun Y, Fang JG (1996) Research on Sanggou Bay aquaculture hydro-environment. Mar Fish Res 17:68-79 (in Chinese with English abstract)

> Zhao Y, Yu Y, Feng W, Shen Y (2003) Growth and production of free-living heterotrophic nanoflagellates in a eutrophic lake-Lake Donghu, Wuhan, China. Hydrobiologia 498:85-95

Submitted: January 27, 2014; Accepted: December 19, 2014 Proofs received from author(s): February 22, 2015 